Loyalitas Kreativitas

Aldi Masyarakat Kreatif
P-ISSN 2722-2101, E-ISSN 2722-4201

Program Studi Ekonomi Manajemen Universitas Pamulang Jurnal LOKABMAS Kreatif Vol.02,No.01,Maret 2021 Hal.110-122

Email:jurnalkreatif.manajemen@gmail.com

\title{
TANTANGAN DAN PROBLEMATIKA KARANG TARUNA SEBAGAI ORGANISASI PENGGERAK PEMUDA MENGHADAPI ERA MILENIUM KEL. PONDOK JAGUNG, SERPONG UTARA KOTA TANGERANG SELATAN
}

\author{
Styo Budi Utomo,Sri sukapti,Iman Lubis,Sonny,Andi Sopandi \\ Dosen Ekonomi Fakultas Ekonomi Universitas Pamulang \\ Email dosen01759@unpam.ac.id, dosen02318@unpam.ac.id, \\ dosen01479@unpam.ac.id,dosen00983@unpam.ac.id dosen02277@unpam.ac.id
}

\begin{abstract}
ABSTRAK
Pengabdian Kepada Masyarakat (PKM) ini bertujuan untuk memberikan pengetahuan kepada Karang Taruna Kec. Serpong Utara Kota Tangerang Selatan tentang Tantangan Dan Problematika Karang Taruna Sebagai Organisasi Penggerak Pemuda Menghadapi Kera Milenium. Selain itu memberikan pengetahuan akan pentingnya mengelola oragnisasi dan kepemimpinan di dalam berorganisasi.

Sasaran kegiatan PKM adalah pemuda Karang Taruna Kec. Serpong Utara Kota Tangerang Selatan Permasalahan diselesaikan melalui tiga (3) tahapan yaitu: persiapan, pelaksanaan dan evaluasi. Dalam kegiatan ini dilakukan dengan cara memberikan penyuluhan dengan materi sesuai kebutuhan dalam berorganisasi.

Hasil kegiatan berjalan sesuai dengan yang diharapkan. Hal ini terlihat dari antusias para peserta. Para peserta memeroleh input dari materi-materi yang disampaikan yang meliputi materi Manajemen Manajemen Konflik dan Organisasi. Kegiatan juga mendapat dukungan penuh dari para civitas kelurahan. Kegiatan ini dinilai menambah khazanah keilmuan bagi para pemuda Karang Taruna.
\end{abstract}

Kata Kunci : manajemen konflik, Tantangan dan problematika organisasi,

\section{ABSTRACT}

This Community Service (PKM) aims to provide knowledge to Karang Taruna Kel. Pondok Benda Kota Tangerang Selatan about how to manage and develop an organization. In addition, it provides knowledge on the importance of managing organizations and leadership in organizations.

The target of PKM activities is youth from the Youth Organization, Kel. Pondok Benda Kec. Pamulang. The problem is resolved through three (3) stages, namely: preparation, 


\section{Loyalitas Kreativitas \\ Aldi Masyarakat Kreatif}

P-ISSN 2722-2101, E-ISSN 2722-4201

Program Studi Ekonomi Manajemen Universitas Pamulang

Jurnal LOKABMAS Kreatif Vol.02,No.01,Maret 2021 Hal.110-122

Email:jurnalkreatif.manajemen@gmail.com

implementation and evaluation. In this activity carried out by providing counseling with material according to organizational needs.

The results of the activity went as expected. This can be seen from the enthusiasm of the participants. The participants received input from the materials presented which included Human Resource Management (HRM) and Organization. The activity also received full support from the urban village community. This activity is considered to add to the scientific treasure of the youth of the Youth Organization.

\section{Keywords: Leadership, Organization}

\section{PENDAHULUAN}

Akhir-kahir ini di Indoensia sudah banyak bermunculan organisasi organisasi di Indonesia. Dengan semakin banyaknya organisasi yang muncul, diharapkan dapat memberikan sebuah karakter tersendiri pada masyarakat tanpa memandang siapa yang menciptakan organisasi tersebut. Merebaknya organisasi yang bermunculan dikahawtirkan akan menimbulkan dampak kepada sosial dan lingkungan sekitar. apad akhir-akhir ini banyak yang mengatasnamakan organisasi masyarakat untuk mendapat uang dengan cara menjual nama organisasi tersbut. oleh karena itu perlu adanya pengenalan berorgaisasi yang benar dan mengelola organisasi tersbut. diharapkan dalam setiaprganisasi akan mampu memabawa tujuan dari masingmasing organisasi.

Salah satu organisasi yang muncul dan terus berkembang hampir disetiap keluarahan ialah organisasi kepemudaan atau karang taruna. Karang Taruna adalah organisasi sosial wadah pengembangan generasi muda yang tumbuh dan berkembang berdasarkan kesadaran dan tanggungjawab sosial dari, oleh dan untuk masyarakat terutama generasi muda di wilayah desa / kelurahan. dengan melalui pemahaman tentang kepemimpinan dan megelola organisasi dengan benar diharapakan para pemuda generasi penerus mampu mewujudkan tujuan dari pada organiasi yang dipimpinnya.Organisasi kepemudaan seperti karang taruna, terutama bagi pemula ikut dalamorganisasi ini harus mengetahui dan memahami tentang suatu organisasi baik organisasi social maupun organisasi yang mneghasilkan profit (perusahaan). Tetapi, pada kesempatan ini menekankan pada sisi kepemimpinan agar kelak bagi peimpinan karang taruna dan atau pemuda karang taruna umumnya agar lebih memahami tentang sikap kepemimpinan dan bagaimana beretika dalam suatu organisasi yang benar.

Tanpa mengesampingkan yang lain, kepemimpinan menjadi titik penting bagi keberhasilan dan kesuksesan suatu organisasi. Seorang pemimpin suatu organisasi yang bijaksana dan baik harus dapat memberikan kepuasan kepada para anggotanya dan selalu berusaha memperhatikan gairah dan semangat mereka. Oleh karena hal tersebut pemimpin harus mempunyai kemampuan dalam mengelola, mengarahkan, mempengaruhi, memerintah dan memotivasi anggota 
Email:jurnalkreatif.manajemen@gmail.com

organisasi untuk mencapai tujuan yang diinginkan. Didalam memimpin organisasi seperti karang taruna dimana tidak ada istilah gaji, honor ataupun bonus, maka pimpinan harus mampu menjalin komunikasi kepada seluruh anggota agar mampu menciptakan suasana keakraban didalam organisasi. Baiknya pemimpin berkomunikasi dengan anggotanya dapat meningkatkan rasa motivasi anggota untuk melakukan yang terbaik bagi organisasinya.

Dalam keadaan ini, timbul pertanyaan mengenai kepemimpinan yang bagaimana yang cocok dan mampu membawa organisasi menghadapi tantangan yang ada. Sehubungan dengan hal tersebut, penulis berupaya memberikan jalan keluar yang berlandaskan pada teori dan konsep kepemimpinan yang dapat membawa organisasi mengatasi tantangan yang akan dibahas dan diharapkan dapat mewujudkan tujuan dari organisasi

\section{RUMUSAN MASALAH}

Dengan mempertimbangkan latar belakang yang telah diutarakan diatas dapat kami rumuskan :

1. Bagiamana kita menyikapi adanya konflik dalam karang taruna di era milenanil ini?

2. Bagiamana kita mengatur karang taruan diera milenial ini?

\section{TUJUAN PELAKS ANAAN}

1. Membantu memberikan arahan terhadap kepala keluarga, wanita ,dan anak-anak apa dampak dari kekerasan dalam rumah tangga .

2. Memberikan semangat dan motivasi bagi kepala keluarga,wanita dan anak anak dalam menjalani kehidupan yang lebih baik

\section{TINJAUAN PUSTAKA}

2.1. Organisai

Organisasi merupakan suatu sistem yang terdiri dari sub-sistem atau bagianbagian yang saling berkaitan satu sama lainnya dalam melakukan aktivitasnya. Aktivitas ini bukanlah merupakan suatu kegiatan yang temporer atau sesaat saja, akan tetapi merupakan kegiatan yang memiliki pola atau urut-urutan yang dilakukan secara relatif teratur dan berulang-ulang. Organisasi sering diartikan sebagai kelompok yang secara bersama-sama ingin mencapai suatu tujuan yang sama. Handoko (2000:6) mendifinisikan organisasi sebagai suatu proses perencanaan yang meliputi penyusunan, pengembangan dan pemeliharaan suatu struktur atau pola hubungan-hubungan kerja dari orangorang dalam suatu kelompok kerja. Artinya, organisasi juga merupakan kumpulan dari peranan, hubungan dan tanggung jawab yang jelas dan tetap, paling tidak Hicks dalam Sutarto (1998:2) berpendapat bahwa hampir setiap orang dipengaruhi secara mendalam oleh kelompok. Sedangkan menurut Louis Allen, Organisasi adalah proses mengidentifikasi dan mengelompokkan pekerjaan yang harus dilakukan, mendefinisikan dan mendelegasikan tanggung jawab dan wewenang dan membangun hubungan untuk tujuan memungkinkan orang untuk bekerja paling efektif bersama dalam mencapai tujuan.

Melibatkan diri dalam beberapa macam kelompok atau organisasi menempatkan kedudukan penting dari kehidupan kebanyakan orang. Artinya, banyak keuntungan dapat diperoleh dari penyempurnaan hubungan antara individu-individu dan kelompok. 
Email:jurnalkreatif.manajemen@gmail.com

Sebagai contoh, berhasilnya suatu usaha sering tergantung dari produktivitas perilaku para individu dalam Kelompok

kerja. Juga seseorang pengusaha harus membagi keberhasilannya dengan para pelanggan, para pemberi sumber dana, material, satuan organisasi pemerintah dan masyarakat umum.

\section{Manfaat Dari Organisasi}

Setelah mengetahui pengertian organisasi yang dipaparkan di atas, maka selanjutnya ada manfaat dari organisasi tersebut. Karena setiap hal tentu memiliki manfaat yang akan diberikan. Di mana manfaat tersebut pada dasarnya memiliki dampak yang bersifat positif sehingga tidak merugikan. Berikut ini merupakan paparan mengenai manfaat dari organisasi.

\section{Meningkatkan Kemampuan Dalam Berkomunikasi}

Komunikasi merupakan suatu hal yang harus dilakukan dengan cara yang sopan apalagi jika berbicara di depan umum. Maka dari itu, selain sopan juga perlu keberanian dalam menyampaikan aspirasi tersebut di depan umum. Karena memang pada dasarnya setiap masuk dalam organisasi tentu harus menyampaikan beberapa pendapat. Dari hal tersebut secara tidak langsung bisa melatih seseorang dalam berkomunikasi.

\section{Dapat Mencapai Tujuan}

Seperti yang dibahas mengenai pengertian organisasi yang tentunya memiliki tujuan yang akan dicapai. Sehingga manfaat dari organisasi tersebut adalah untuk mencapai tujuan dengan mudah bersama dengan para anggota. Karena setiap tujuan tentunya akan dibagi dengan anggota lainnya. Selain itu, tujuan dari organisasi tersebut juga harus memiliki susunan yang sistematis.

\section{Menjadi Motivasi Dalam} Membangkitkan Jiwa Pemimpin

Dalam organisasi tentu setiap anggota akan bersaing untuk menjadi seorang ketua atau pemimpin dari organisasi tersebut. Maka dari itu, organisasi bisa memberikan manfaat dalam membangkitkan jiwa pemimpin. Namun untuk menjadi pemimpin dalam sebuah organisasi harus mementingkan masalah organisasi dibandingkan dengan masalah individu.

4. Mampu Memecahkan Masalah yang Ada

Masalah dalam setiap organisasi memang biasanya terjadi dalam waktu yang tidak ditentukan. Baik masalah tersebut bersifat kecil maupun besar yang disebabkan dari berbagai hal. Seperti disebabkan karena memiliki perbedaan pendapat dari anggota. Maka dari itu, permasalahan yang timbul tersebut harus diselesaikan dengan menunjukkan sikap yang lebih kompleks dan majemuk.

5. Memperluas Wawasan yang Dimiliki Wawasan merupakan sebuah pengetahuan yang didapatkan dari mana saja dan kapan pun. Salah satunya dengan masuk dalam sebuah organisasi untuk memperluas wawasan tersebut. Di mana wawasan ini di dapatkan dengan mengikuti seminar, diskusi, dan agenda lain yang ada di dalam organisasi. Sehingga hal tersebut bisa memberikan pengetahuan baru untuk memperluas wawasan.

6. Memperluas Pergaulan dan Mengatur Waktu 
Email:jurnalkreatif.manajemen@gmail.com

Dalam organisasi memang terbagi dari beberapa orang yang berasal dari berbagai kalangan yang berbeda. Sehingga hal tersebut menyebabkan setiap anggota organisasi bisa memperluas pergaulan yang ada. Selain itu, bisa juga melatih kedisiplinan dalam mengatur waktu yang dimiliki. Karena memang kegiatan yang dimiliki bukan hanya organisasi saja tetapi memiliki aktivitas lain.

7. Memiliki Rasa Tanggung Jawab Yang Tinggi

Manfaat lainnya adalah setiap anggota organisasi memiliki rasa tanggung jawab yang tinggi. Di mana tanggung jawab yang dimaksud adalah bertanggung jawab terhadap apa yang menjadi amanah. Seperti bertanggung jawab terhadap amanah pada saat menjabat sebagai pemimpin atau ketua dari organisasi. Sehingga seorang pemimpin ini harus melaksanakan hal tersebut dengan baik.

8. Memiliki Mental Yang Kuat Pada Saat Menghadapi Tekanan

Mental yang kuat memang harus dipersiapkan terlebih dahulu sebelum masuk atau bergabung dalam sebuah organisasi. Karena memang pada dasarnya ada tekanan yang muncul dari pihak lain untuk bersikap tegas dan tahan banting. Selain itu, anggota organisasi akan digembleng sehingga terbiasa untuk menghadapi tekanan tersebut. Oleh karena itu, kepribadian seseorang akan menjadi lebih percaya diri dan disiplin.

Fungsi yang Didapatkan Dalam Berorganisasi

Selain pengertian organisasi dan manfaat dari organisasi tersebut, ada pula fungsi organisasi yang harus diketahui. Sama halnya dengan manfaat organisasi, fungsi organisasi juga memiliki dampak yang bersifat positif bagi para pelakunya. Berikut ini merupakan paparan mengenai fungsi yang didapatkan dalam berorganisasi.

1. Memberikan Arahan

Dalam memberikan arahan yang dimaksud adalah organisasi bisa mengajarkan seseorang mengenai apa yang baik dan yang buruk. Dalam hal ini organisasi akan memberitahukan mengenai apa yang baik dilakukan dan apa yang buruk sehingga tidak bisa dilakukan. Selain itu, mengenai arahan tersebut adalah dapat juga dilihat dari pembagian kerja yang diberikan untuk setiap anggota.

2. Meningkatkan Skill

Selanjutnya dengan berorganisasi adalah dapat meningkatkan skill yang dimiliki oleh setiap anggota, dimana skill yang dimaksud adalah seperti untuk menjadi seorang pemimpin dan berbicara di depan umum.

Hal tersebut bisa didapatkan ketika masuk dalam sebuah organisasi, karena Anda akan memiliki motivasi untuk meningkatkan kemampuan yang dimiliki tersebut. Oleh Karena itu, cara berbicara di depan umum tidak gugup.

3. Mendapatkan Pengalaman Baru

Pengalaman yang didapatkan dari organisasi tentu saja tidak bisa didapatkan dari kegiatan lainnya. Karena kegiatan yang dilakukan dalam sebuah organisasi merupakan suatu pelajaran yang sangat berharga. Di mana pengalaman baru yang bisa di dapatkan tersebut seperti membuat laporan dari kegiatan organisasi yang telah dilakukan. Selain itu, bisa pula memiliki pengalaman saat menjadi pemimpin.

4. Mampu Artikulasi dan Agregasi 
Dalam fungsi yang satu ini dijadikan sebagai instrumen yang mampu dalam artikulasi dan agregasi sebuah kepentingan umum dan individu. Untuk fungsi yang satu ini bisa didapatkan jika bergabung dengan organisasi yang berbasis internasional. Karena bisa dijadikan sebagai bentuk dari kontak institusionalisme dengan partisipan aktif. Di mana hal yang dimaksud tersebut adalah forum diskusi dan negosiasi.

\section{Norma dan Rekrutmen}

Fungsi organisasi selanjutnya adalah memberikan kontribusi yang memiliki arti penting untuk berbagai aktivitas yang bersifat normatif. Di mana contoh dari hal tersebut seperti penetapan nilainilai tertentu. Selain itu, organisasi juga memiliki fungsi sebagai rekrutmen atau menarik setiap anggota untuk menjadi partisipan.

\subsection{Manajemen Konflik}

Keberadaan konflik dalam suatu organisasi tidak dapat dihindarkan. Konflik sering muncul dan terjadi pada setiap organisasi, ada beberapa pandangan pakar mengenai konflik. Mitchell, B., Setiawan, B. dan Rahmi, D. H. (dalam Wahyudi, 2006) menjelaskan bahwa konflik atau pertentangan pada kondisi tertentu mampu mengidentifikasi sebuah proses pengelolaan lingkungan dan sumber daya yang tidak berjalan secara efektif, mempertajam gagasan, bahkan dapat menjelaskan kesalahpahaman. Dalam kehidupan yang dinamis antarindividu dan antarkomunitas, baik dalam organisasi maupun di masyarakat yang majemuk, konflik selalu terjadi manakala kepentingan saling berbenturan.
Beberapa Pandangan tentang Konflik dalam Organisasi

Robbins(2003:137) mengemukakan tiga pandangan mengenai konflik, yaitu pandangan tradisional (traditional view of conflict), pandangan hubungan manusia (human relations view of conflict) dan pandangan interaksonis (interactionism view of conflict).

1. Pandangan tradisional ini menganggap konflik sebagai hasil disfungsional akibat komunikasi yang buruk, kurangnya keterbukaan dan kepercayaan antara orang-orang dan kegagalan para manajer untuk tanggap terhadap kebutuhan dan aspirasi para karyawan. Semua konflik adalah buruk, dipandang secara negatif dan disinonimkan dengan istilah kekerasan, perusakan dan ketidakrasionalan serta memiliki sifat dasar yang merugikan dan harus dihindari.

2. Pandangan hubungan manusia menyatakan bahwa konflik merupakan peristiwa yang wajar dalam semua kelompok dan organisasi. Karena konflik itu tidak terelakan, aliran hubungan manusia menganjurkan penerimaan konflik. Konflik tidak dapat disingkirkan dan bahkan adakalanya konflik membawa manfaat pada kinerja kelompok.

3. Pendekatan interaksionis mendorong terjadinya konflik atas dasar bahwa kelompok yang kooperatif, tenang,

4. Teori Sedang Tumbuh damai serasi cenderung menjadi statis, apatis dan tidak tanggap terhadap kebutuhan akan perubahan dan inovasi. Oleh karena itu, sumbangan utama dari pendekatan interaksionis adalah mendorong pemimpin kelompok untuk mempertahankan suatu tingkat 
Email:jurnalkreatif.manajemen@gmail.com

minimum berkelanjutan dari konflik. Dengan adanya pandangan ini menjadi jelas bahwa untuk mengatakan bahwa konflik itu seluruhnya baik atau buruk tidaklah tepat.

Secara teoretik Robbins (1996: 438) mengemukakan dua tipe konflik, yaitu

konflik fungsional dan konflik disfungsional. Konflik fungsional adalah sebuah konfrontasi di antara kelompok yang menambah keuntungan kinerja organisasi. Konflik disfungsional adalah setiap konfrontasi atau interaksi di antara kelompok yang merugikan organisasi atau menghalangi pencapaian tujuan organisasi.

Konflik didefinisikan sebagai suatu proses interaksi sosial di mana dua orang atau lebih, atau dua kelompok atau lebih, berbeda atau bertentangan dalam pendapat atau tujuan mereka (Cummings, P. W. dalam Wahyudi, 2006). Tidak berbeda dengan pendapat di atas, Alisjahbana, S.T. (dalam Wahyudi, 2006), mengartikan konflik sebagai perbedaan pendapat dan pandangan diantara kelompokkelompok masyarakat yang akan mencapai nilai yang sama. Sedangkan Stoner, J. A. F. \& Freeman, R. E. (dalam Wahyudi, 2006) berpendapat bahwa konflik organisasi mencakup ketidaksepakatan soal alokasi sumberdaya yang langka atau perselisihan soal tujuan, status, nilai, persepsi, atau kepribadian.

Perbedaan pendapat dan persepsi mengenai tujuan, kepentingan maupun status serta nilai individu dalam organisasi merupakan penyebab munculnya konflik. Demikian halnya persoalan alokasi sumberdaya yang terbatas dalam organisasi dapat menimbulkan konflik antarindividu maupun antarkelompok.

Luthans, F. (dalam Wahyudi, 2006) mengartikan konflik merupakan ketidaksesuaian nilai atau tujuan antara anggota organisasi, sebagaimana dikemukakan berikut, "Conflict has been defined as the condition of ovjective incompatibility between values or goal, as the behaviour of deliberately interfering with another's goal achievement, and emotionally in term of hostility". Lebih lanjut dikemukakan oleh Luthans, perilaku konflik dimaksud adalah perbedaan kepentingan/minat, perilaku kerja, perbedaan sifat individu dan perbedaan tanggung jawab dalam aktivitas organisasi. Pendapat yang hampir sama dikemukakan oleh Walton, R. E. (dalam Wahyudi, 2006) yang menyatakan bahwa konflik organisasi adalah perbedaan ide atau inisiatif antara bawahan dengan bawahan, manajer dengan manajer dalam mengkoordinasikan kegiatan-kegiatan (coordinated activities). Perbedaan inisiatif dan pemikiran sebagai upaya identifikasi masalah-masalah yang menghambat pencapaian tujuan organisasi.

Dubrin, A. J. (dalam Wahyudi, 2006), mengartikan konflik mengacu pada pertentangan antarindividu atau kelompok yang dapat meningkatkan ketegangan sebagai akibat saling menghalangi dalam pencapaian tujuan sebagaimana dikemukakan sebagai berikut: "Conflict in the context used, refers to the positions of persons of forces that gives rise to some tension. It occurs when two or more parties (individuals, groups, organization) perceive mutually exclusive goals, or 
events". Hal senada dikemukakan juga oleh Hardjana (1994) bahwa konflik adalah perselisihan, pertentangan antara dua orang/ dua kelompok di mana perbuatan yang satu berlawanan dengan yang lainnya sehingga salah satu atau keduanya saling terganggu. Kedua pendapat terakhir menganggap bahwa pertentangan antar individu dan kelompok sebagai perilaku yang mengganggu pencapaian tujuan organisasi. Dengan demikian konflik diartikan sebagai peristiwa yang dapat merugikan organisasi.

Pengertian yang lebih lengkap dikemukakan oleh Stoner dan Wankel (1986) bahwa konflik organisasi adalah ketidaksesuaian antara dua orang anggota organisasi atau lebih yang timbul karena fakta bahwa mereka harus berbagi dalam hal mendapatkan sumbersumber daya yang terbatas, atau aktivitas-aktivitas pekerjaan dan atau karena fakta bahwa mereka memiliki status, tujuan, nilai-nilai atau persepsi yang berbeda. Sedangkan Aldag, R. J. dan Stearns, T. M. (dalam Wahyudi, 2006) secara tegas mengartikan konflik sebagai ketidaksepahaman antara dua atau lebih individu/kelompok sebagai akibat dari usaha kelompok lainnya yang mengganggu pencapaian tujuan. Dengan kata lain, konflik timbul karena satu pihak mencoba untuk merintangi mengganggu pihak lain dalam usahanya mencapai suatu tujuan.

Dengan demikian, suatu organisasi yang sedang mengalami konflik dalam aktivitasnya menunjukkan ciri-ciri sebagai berikut.

a. Terdapat perbedaan pendapat atau pertentangan antar individu atau kelompok. b. Terdapat perselisihan dalam mencapai tujuan yang disebabkan adanya perbedaan persepsi dalam menafsirkan program organisasi.

c. Terdapat pertentangan norma dan nilainilai individu maupun kelompok.

d. Adanya sikap dan perilaku saling meniadakan, menghalangi pihak lain mendapat kemenangan dalam memperebutkan sumber daya organisasi yang terbatas.

e. Adanya perdebatan dan pertentangan sebagai akibat munculnya kreativitas, inisiatif atau gagasan-gagasan dalam mencapai tujuan organisasi.

\section{PROSES TERJADINYA KONFLIK}

Konflik tidak terjadi secara mendadak tanpa sebab dan proses, akan tetapi melalui tahapan-tahapan tertentu. Hendricks, W. (1992) mengidentifikasi proses terjadinya konflik terdiri dari tiga tahap.

1) Peristiwa sehari-hari; ditandai adanya individu merasa tidak puas dan jengkel terhadap lingkungan kerja. Perasaan tidak puas kadang-kadang berlalu begitu saja dan muncul kembali saat individu merasakan adanya gangguan.

2) Adanya tantangan; apabila terjadi masalah,individu saling mempertahankan pendapat dan menyalahkan pihak lain. Tiap anggota menganggap perbuatan yang dilakukan sesuai dengan standar dan aturan organisasi. Kepentingan individu maupun kelompok lebih menonjol daripada kepentingan organisasi.

3) Timbulnya pertentangan; masingmasing individu atau kelompok bertujuan untuk menang dan mengalahkan kelompok lain.

Robbins (2003) menjelaskan konflik 
Loyalitas Kreativitas

Aldi Masyarakat Kreatif
P-ISSN 2722-2101, E-ISSN 2722-4201

Program Studi Ekonomi Manajemen Universitas Pamulang

Jurnal LOKABMAS Kreatif Vol.02,No.01,Maret 2021 Hal.110122

Email:jurnalkreatif.manajemen@gmail.com terjadi melalui lima tahap, yaitu tahap oposisi atau ketidakcocokan potensial, tahap kognisi dan personalisasi, tahap maksud, tahap perilaku dan tahap hasil. Tahap I: Oposisi atau Ketidakcocokan Potensial

Langkah pertama dalam proses komunikasi adalah adanya kondisi yang menciptakan kesempatan untuk munculnya konflik itu. Kondisi itu tidak perlu langsung mengarah ke konflik,

kondisi yang juga dapat dipandang sebagai kasus atau sumber konflik telah dimampatkan ke dalam tiga kategori umum: komunikasi, struktur dan variabel pribadi.

\section{Tahap II: Kognisi dan Personalisasi}

Jika kondisi-kondisi yang disebut dalam Tahap I mempengaruhi secara negatif sesuatu yang diperhatikan oleh satu pihak, maka potensi untuk oposisi atau ketidakcocokan menjadi teraktualkan dalam tahap kedua. Kondisi anteseden hanya dapat mendorong ke konflik bila satu pihak atau lebih dipengaruhi oleh dan sadar akan adanya, konflik itu. Tahap II penting karena di situlah persoalan konflik cenderung didefinisikan.

\section{Tahap III: Maksud}

Maksud merupakan keputusan untuk bertindak dalam suatu cara tertentu. Dapat diidentifikasikan lima maksud penanganan konflik: bersaing (tegas dan tidak kooperatif), berkolaborasi (tegas dan kooperatif), menghindari (tidak tegas dan tidak kooperatif), mengakomodasi (kooperatif dan tidak tegas) dan berkompromi (tengah-tengah dalam hal ketegasan dan kekooperatifan).
Tahap IV: Perilaku

Perilaku konflik ini biasanya secara terang-terangan berupaya untuk melaksanakan maksud-maksud setiap pihak. Tetapi perilaku-perilaku ini mempunyai suatu kualitas rangsangan yang terpisah dari maksud. Sebagai hasil perhitungan atau tindakan yang tidak terampil, kadangkala perilaku terang- terangan menyimpang dari maksud- maksud yang orsinil.

Tahap V: Hasil

Jalinan aksi-reaksi antara pihak- pihak yang berkonflik menghasilkan konsekuensi. Hasil ini dapat fungsional, dalam arti konflik itu menghasilkan suatu perbaikan kinerja kelompok, atau disfungsional dalam arti merintangi kinerja kelompok.

\section{PENYEBAB KONFLIK}

Konflik melalui proses dan terdapat kondisi yang mendahuluinya. Hardjana, A. M. (dalam Wahyudi, 2006) menyebutkan lingkaran konflik terdiri dari hal-hal sebagai berikut: (1) kondisi yang mendahului, kemungkinan konflik yang dilihat, (3) konflik yang dirasa, (4) perilaku yang nampak, (5) konflik ditekan atau dikelola dan (6) dampak konflik. Sedangkan Terry, G. R. (1986) menjelaskan bahwa konflik pada umumnya mengikuti pola yang teratur yang ditandai timbulnya suatu krisis, selanjutnya terjadi kesalahpahaman antar individu maupun kelompok dan konfrontasi menjadi pusat perhatian, pada tahap berikutnya krisis dialihkan untuk diarahkan dan dikelola.

Konflik bersumber dari berbagai macam 
persoalan yang ada dalam organisasi. Davis dan Newstrom (1981 :209) berpendapat bahwa konflik muncul disebabkan oleh, "Organizational change, personality clashes, different sets of values, threats to status, constrasting perceptions and points of view. Organisasi yang dinamis selalu mengalami perubahan dan perubahan yang terjadi sebagai usaha menyesuaikan perkembangan ilmu pengetahuan dan teknologi, ataupun berupaya meningkatkan pelayanan

kepada pihak-pihak yang berkepentingan (stake holders).

Secara singkat, Dubrin, A. J. (1984: 350354) mengemukakan bahwa sebagian besar konflik disebabkan oleh sifat agresif individu-individu, persaingan sumber- sumber yang terbatas, perbedaan kepentingan dan tujuan, terjadi kesalahpahaman dalam menafsirkan tujuan, persaingan peran, persaingan jabatan, ketidakjelasan dalam menentukan tugas, perubahan organisasi, iklim organisasi yang tidak menyenangkan, godaan seksual bagi karyawan wanita, pelanggaran terhadap wilayah kerja dan perbedaan pengetahuan. Sebab-sebab utama konflik menurut Cummings, P. W. (1980), yaitu spesialisasi pekerjaan, perubahan nilai-nilai, kurang perhatian dalam hubungan manusia, pelanggaran wilayah kerja, penggabungan dua departemen/unit kerja.

Sementara itu Hardjana, A. M. (1994) menyimpulkan bahwa secara umum sumber-sumber konflik dalam organiasi sebagai berikut: (1) salah pengertian karena kegagalan komunikasi, (2) perbedaan tujuan karena perbedaan nilai hidup, (3) persaingan mendapatkan sumber daya otganisasi yang terbatas, (4) masalah wewenang dan tanggung jawab (5) perbedaan penafsiran terhadap peraturan atau kebijakan, (6) kurangnya kerjasama (7) adanya usaha untuk mendominasi, (8) tidak menaati tata tertib dan peraturan kerja dan (9) perubahan dalam sasaran dan prosedur kerja.

Tosi, H.L., Rizzo, J.R. dan Carrol, S.J. (1990: 523) mengelompokkan sumbersumber konflik menjadi tiga, yaitu (1) Individual characteristic, (2) Situational conditions dan (3) Organizations structure. Karakteristik individu meliputi: perbedaan individu dalam hal nilai-nilai, sikap, keyakinan, kebutuhan dan kepribadian, persepsi ataupun pendapat. Situasi kerja terdiri dari; saling ketergantungan untuk menjalin kerjasama, perbedaan pendapat antar departemen, perbedaan status, kegagalan komunikasi, kekaburan bidang tugas. Penyebab konflik yang ketiga adalah struktur organisasi yaitu, spesialisasi pekerjaan, saling ketergantungan dalam tugas dalam tugas, perbedaan tujuan, kelangkaan sumber- sumber

\section{METODE PELAKSANAAN}

Metodepelaksanaan pengabdian ini dilakukan dalam beberapa kegiatan yaitu tahap survei yaitu sosialisasi dilakukan dengan menyusun berbagai hal yang akan disampaikan pada saat kegiatan pengabdian yang akan dilakukan yang meliputi: penyusunan materi yang akan diberikan, penyusunan jadwal pemberian materi, pembagian tugas tim pengabdian dan survei ke lokasi pengabdian. Tahap sosialisasi yaitu sebelum kegiatan pengabdian 
Email:jurnalkreatif.manajemen@gmail.com

dilaksanakan terlebih dahulu dilakukan tahap sosialisasi yaitu melakukan silaturahmi dengan ketua yayasan, menyampaikan maksud dan tujuan pengabdian ini. Pada tahap ini juga dilakukan jalinan kerjasama dan menentukan jadwal kegiatan pengabdian. Tim pelaksana kegiatan pengabdian pada masyarakat adalah dosen Fakultas Ekonomi jurusan manajemen sebanyak 8 orang. Tim pengabdian memberikan materi tentang tantangan dan problematika karang taruna sebagai organisasi penggerak pemuda menghadapi era milenium

hasil dan pembahasan bekerjasama antara UNPAM dengan Karang Taruna Kelurahan Pondok Jagung Kec. Serpong Utara Kota Tangerang Selatan Banten.

Pengabdian Masyarakat (LPPM) Universitas Pamulang yang dilakukan oleh dosen-dosen program studi Manajemen telah berjalan dengan lancar dan mendapat sambutan hangat dari tempat pelaksanaan kegiatan ini oleh KEpala KElurahan dan Ketua Karang Taurna Kec. Serpong Utara yang dihadiri oleh masing-masing ketua karang taruna dan anggota disetiap kelurahan sekecamatan Serpong Utara.

Harapan kami dengan pengabdian ini dapat membuka wawasan dann paradigma tentang materi ini oleh anggota karang taruna serta diperoleh adalah bertambahnya keilmuan bagi para ketua karang taruna agar dapat mengelola konflik yang muncul pada oragnisasi yang mereka pimpin.

\section{KESIMPULAN DAN SARAN}

Kegiatan PKM yang dilaksanakan di Kel. Pondok Jagung Kota Tangerang Selatan berjalan sesuai dengan apa yang diharapkan, dimana para peserta bisa mendapatkan input dari materi-materi yang disampaikan narasumber.

Saran

1. Melihat respon dari kegiatan PKM yang dilakukan di Kel. Pondok Jagung Kota Tangerang Selatan ini, kegiatan PKM sepatutnya masih difokuskan pada Karang Taruna.

2. Kegiatan PKM pada Karang Taruna hendaknya masih difokuskan pada materi-materi yang terkait dengan manajemen, sumber daya manusia dan organisasi dengan tujuan membangun jiwa kepemimpinan dan nasionalis.

3. Kegiatan PKM dengan sasaran Karang Taruna membangun brand image Unpam selain sebagai tempat belajar juga sebagai penggerak organisasi.

\section{Saran}

Sebagai anggota didalam sebuah organisasi mauapu perusahaan diharapkan mampu melaksanakan tugas dengan baik. Melalui budaya dan kepemimpinan yang baik maka tujuan dari sebuah organisasi akan tercapai dengan baik juga.

\section{DAFTAR PUSTAKA}

Allen Louis, https://projasaweb.com/pengertianorganisasi/

Gibson, James L., 2010. Kepemimpinan Organisasi: Perilaku dan Struktur. Jakarta: Erlangga. 
Email:jurnalkreatif.manajemen@gmail.com

Hardjana, A.M. 2003. Komunikasi Intrapersonal \& Interpersonal, Jakarta. Kanisius.

Hasibuan, Malayu S. P., 2009. Manajemen Sumber Daya Manusia. Jakarta: Bumi Aksara.

Hasibuan.Malayu.SP; 2008.Organisasi dan Motivasi Jakarta: Bumi Aksara Ishak dan Hendri Tanjung; 2010.Manajemen Motivasi. Jakarta. PT. Grasindo.Jakarta

Priono, 2007, Pengantar Manajemen, Zifatama Pubblisher, Sidoarjo https://accurate.id/marketingmanajemen/pengertian-organisasi/

Donald K. Freedheim \& Irving B. Weiner. 2003. Handbook of Psychology: Volume l, History of Psychology, John Wiley \& Sons, Inc., New Jersey

Eagly, A. H., Johannesen-Schmidt, M. C., \& van Engen, M. L. 2003. Transformational, transactional, and laissez-faire leadership styles: A meta-analysis comparing women and men. Psychological Bulletin, 129, 569-591.

Kruglanski, A.W., E. Tory Higgins (ed) . 2007. Social Psychology : Handbook of Basic Principles, The Guilford Press, New York

Littlejohn, Stephen W. "Theories of Human Communication" Seventh Editions; Relmont California, Wadsworth Publishing Company, 2002
Noe, Hollenbeck, Gerhart, Wright. 2000. Human Resource Management:Gaining a Competitive Advantage. International Edition.. Third Edition. McGraw-Hill Companies. Inc.

Rakhmat, Jalaluddin. "Psikologi Komunikasi" edisi revisi. Remaja Rosdakarya. Bandung, 1998

Reece, B.L \& Rhonda Brand. 1993. Effective Human Relations in Organization, Houghton Mifflin Company, Boston-Toronto

\section{DOKUMENTASIFOTO KEGIATAN}

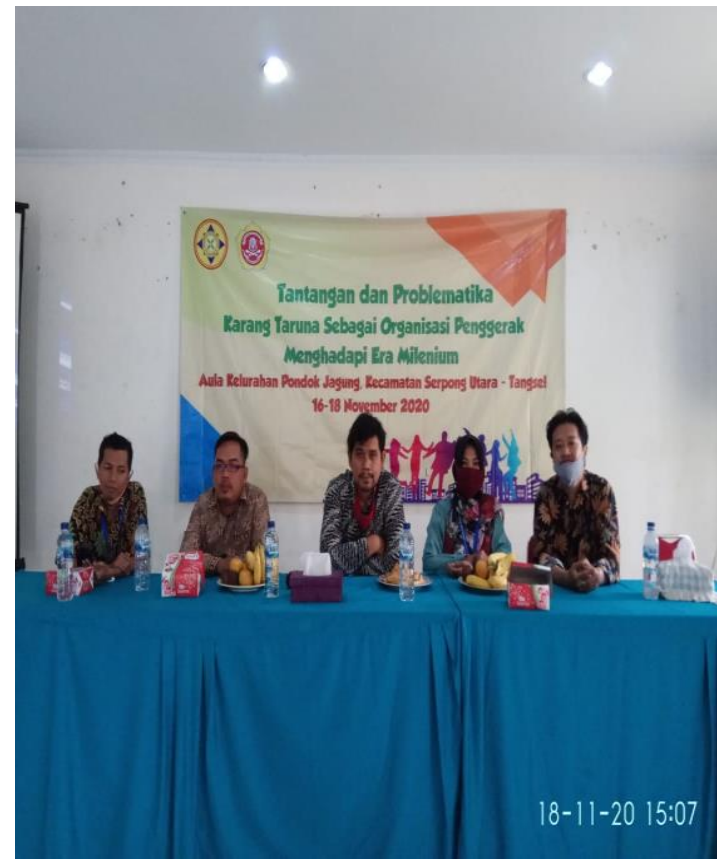


Loyalitas Kreativitas

Aldi Masyarakat Kreatif
P-ISSN 2722-2101, E-ISSN 2722-4201

Program Studi Ekonomi Manajemen Universitas Pamulang Jurnal LOKABMAS Kreatif Vol.02,No.01,Maret 2021 Hal.110122

Email:jurnalkreatif.manajemen@gmail.com
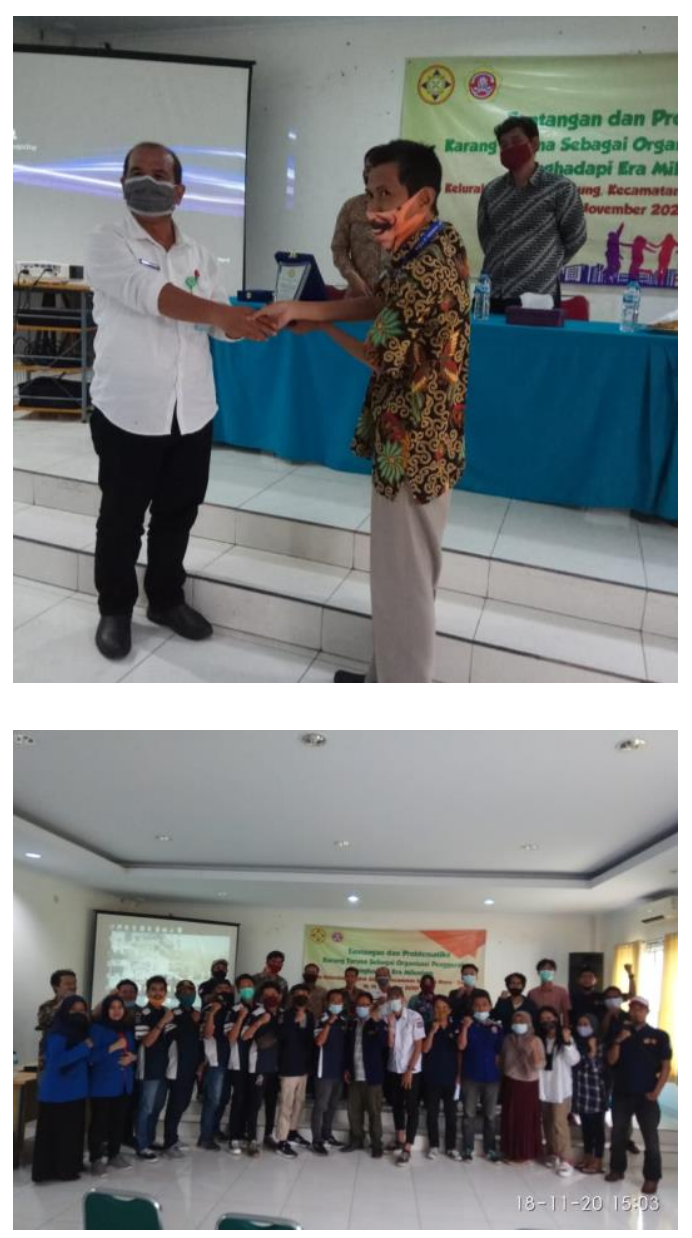